\title{
The effect of pretreatment using sodium hydroxide and acetic acid to biogas production from rice straw waste
}

\author{
Budiyono ${ }^{1, *}$, Aryantoko Wicaksono ${ }^{1}$, Arif Rahmawan ${ }^{1}$, Hashfi Hawali Abdul Matin ${ }^{2}$, Larasati Gumilang Kencana \\ Wardani $^{2}$, Tutuk Djoko Kusworo ${ }^{1}$, and Siswo Sumardiono ${ }^{1}$ \\ ${ }^{1}$ Department of Chemical Engineering, Diponegoro University, 50275 Semarang, Indonesia \\ ${ }^{2}$ Department of Environmental Engineering, Diponegoro University, 50275 Semarang, Indonesia
}

\begin{abstract}
Rice straw is agricultural waste containing high potency to be treated to biogas. However, the usage of rice straw is still limited due to high lignin content that will cause low biodegradability. The aim of this research was to study the effect of pretreatment using $\mathrm{NaOH}$ and acetic acid to biogas production from rice straw. $\mathrm{NaOH}$ was varied from $2 \% \mathrm{w}, 4 \% \mathrm{w}$, and $6 \% \mathrm{w}$; and acetic acid was varied from $0,075 \mathrm{M}$, $0,15 \mathrm{M}$ dan $0,75 \mathrm{M}$. The rice straw was cut into $1 \mathrm{~cm}$ size and submerged for 30 minutes in $\mathrm{NaOH}$ and acetic acid solution. The rice straw then filtered and neutralized before sending to anaerobic digestion process using rumen fluid bacteria. Biogas produced was measured using water displacement method. The result showed that the optimum concentration of $\mathrm{NaOH}$ solution was $4 \% \mathrm{w}$ that resulted in biogas volume of $21,1 \mathrm{ml} / \mathrm{gTS}$. Meanwhile, the optimum concentration of acetic acid pretreatment was $0,075 \mathrm{M}$ that produced biogas volume of $14,5 \mathrm{ml} / \mathrm{gTS}$. These results suggest that pretreatment using $\mathrm{NaOH}$ solution is more effective for decreasing the lignin content from rice straw.
\end{abstract}

\section{Introduction}

Indonesia is an agricultural country with a large agricultural sector, namely rice. Rice is the staple food majority of Indonesian people. Results of production are in the form of rice bran, straw and chaff. The agricultural waste which is potentially to be developed and processed into an environmentally friendly alternative energy is rice straw [19]. In some countries, rice straw has been converted and processed into other materials or products such as paper and pulp, organic fertilizers, mushroom cultivation media, building materials, handicrafts, animal feed, and in the process of burning the bricks to reduce energy consumption [22]

The amount of rice straw in Indonesia is very large because Indonesia is one of the largest rice producer in the world. Rice production was recorded in 2012 (ASEM) amounted to 69.05 million tons of dry rice husk (GKG) or an increase of 3.29 million tons (5.00 percent) compared to 2011. The increase in production occurred in Java amounted to 2.12 million ton and outside Java at 1.17 million tons. The increase in production occurs due to increasing harvested area 239.80 thousand hectares ( 1.82 percent) and the increase in productivity by 1.56 quintal / hectare (3.13 per cent) (CBS, 2013).

Rice straw is agricultural waste which has high cellulose content that causes their utilization is not optimal. According to Stacey (1976), there is a lot of alternative usage for rice straw i.e. to make biogas via fermentation process by converting cellulose into glucose which is the most important process in the fermentation process. Cellulose content in rice straw amounting to $33.9 \%$, while the hemicellulose by $10.2 \%$ $25.6 \%$ to lignin content [14].

\section{Materials and methods}

Biogas production process was using waste rice straw as raw material obtained from the Village Somomoro, District Plupuh Sragen. The adjuvant to speed up the process of decay and fermentation was using Rumen obtained from slaughterhouses (Slaughterhouse) in Semarang. Distilled water, $\mathrm{NaOH}$ (sodium Hydroxide), $\mathrm{CH}_{3} \mathrm{COOH}$ (Acetic Acid) and $\mathrm{H}_{2} \mathrm{SO}_{4}$ (sulfuric acid) were obtained from local chemical store Indrasari in Semarang. The initial stage of the research was cutting the hay to a size of $1 \mathrm{~cm}$ and then added to a solution of acetic acid $(0,075 \mathrm{M}, 0,15 \mathrm{M}$ and $0,75 \mathrm{M})$ and a solution of $\mathrm{NaOH}(2 \% \mathrm{w}, \mathrm{w} 4 \%$ and $6 \% \mathrm{w})$. Soaking was performed for 30 minutes and then followed by filtering and washing so that the $\mathrm{pH}$ of the straw was neutral before it entered the next stage.

Research carried out by inserting a rice straw from initial research results with a ratio of 10 grams (weight) rumen : water : rice straw that is $2: 1: 1$ [24]. A series laboratory test of $400 \mathrm{ml}$ biodigester was operated in batch system. The main experiment apparatus consists of biodigester and biogas measurement.

\footnotetext{
* Corresponding author : budiyono@che.undip.ac.id
} 


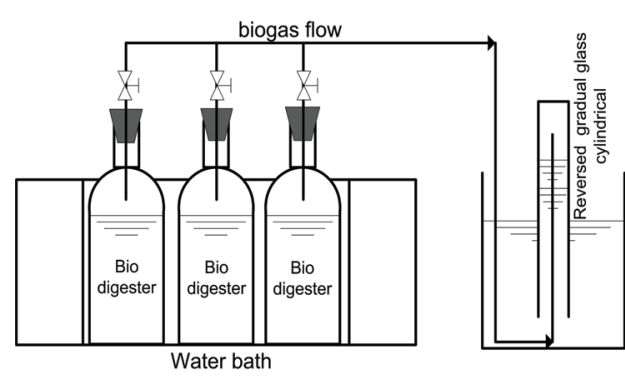

Fig. 1. Schematic diagram of series laboratory batch assessment of anaerobic digestion

Biodigester was made from polyethylene bottle plugged with tightly rubber plug and equipped with valve for biogas measurement. The temperature of biodigester was maintained at certain value using thermostatically controlled electrically heated water bath. Biogas formed was measured by "liquid displacement method" as also has been used by researchers before (3, $4-5,21]$ The schematic diagram of experimental laboratory set up as shown in Figure 1.

\section{Results and discussion}

\subsection{Effect of pretreatment on the production of biogas from straw}

Pretreatment is one of the first steps to degrade lignin compounds that interfere with the process of the formation of biogas from a biomass, due to the presence of lignin compounds can inhibit the fermentation process by microorganisms. Delignification was carried out with the addition of two different chemical solutions i.e. using solution of acetic acid $\left(\mathrm{CH}_{3} \mathrm{COOH}\right)$ [25] and using an alkaline solution $(\mathrm{NaOH})$ [8]. Pretreatment is expected to degrade lignin content in rice straw and accelerates the decomposition process of rice straw to obtain optimal biogas yield [15]. Effect of early treatment on the production of biogas from rice straw can be seen in the graph below.

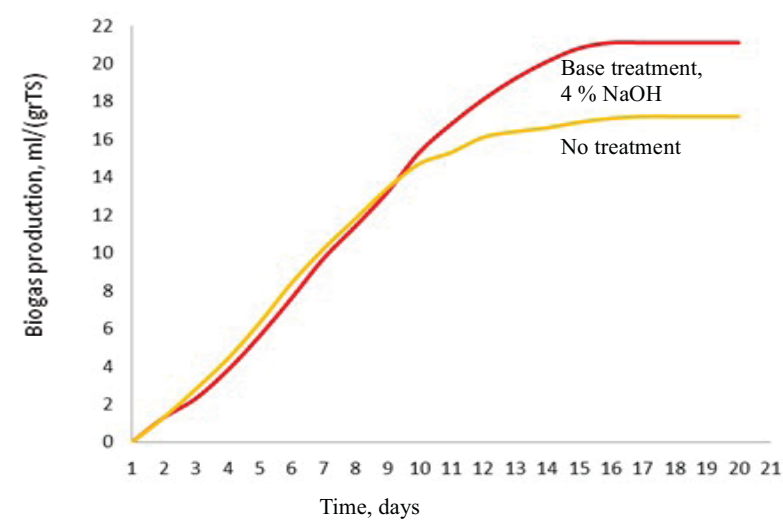

Fig. 2. Effect of Pretreatment in biogas production

In the process of biogas production from rice straw, pretreatment can increase the production of biogas. The optimum volume resulting from one of the variables pretreatment with an alkaline solution of $4 \% \mathrm{w}$ i.e 21.1 $\mathrm{ml} /$ grTS whereas without pretreatment only 17.2 $\mathrm{ml} /$ grTS. Differences in the volume of biogas produced shows that there is an increasing volume of biogas at their initial treatment compared with rice straw without any pretreatment. This is in accordance with the research conducted by [18] which explained that early treatment will reduce lignin compounds in lignocellulose structure. Research conducted by [9] also explained that early treatment will also separate the main components namely cellulose as a source of nutrients for the biogas making bacteria. Lignin compounds would interfere with biogas forming bacteria, consequently biogas production results are not optimal. This can be seen in Figure 2 that shows the pretreatment will increase the production of biogas compared with without pretreatment.

\subsection{Effect of $\mathrm{NaOH}$ solution on Biogas Production from Rice Straw}

Pretreatment by immersion using an alkaline solution is one important step in the process of biogas production. Pretreatment on rice straw biodegradation can accelerate and raise the volume of biogas production [8]. Their initial treatment on a substrate to produce biogas is characterized by decreased levels of lignin in a substrate. In the study conducted using substrates such as rice straw pick the cellulose content is quite high at around $31 \%$, while $28 \%$ hemicellulose, lignin with $12 \%$ in the control variable. $\mathrm{NaOH}$ alkaline solution is selected as the initial treatment because besides the cheap price is also effective in reducing the lignin content or degrade lignin in rice straw. Here's a graph of the results of studies using $\mathrm{NaOH}$ alkaline solution as a medium pretreated by soaking for 30 minutes before the main process in the manufacture of biogas.

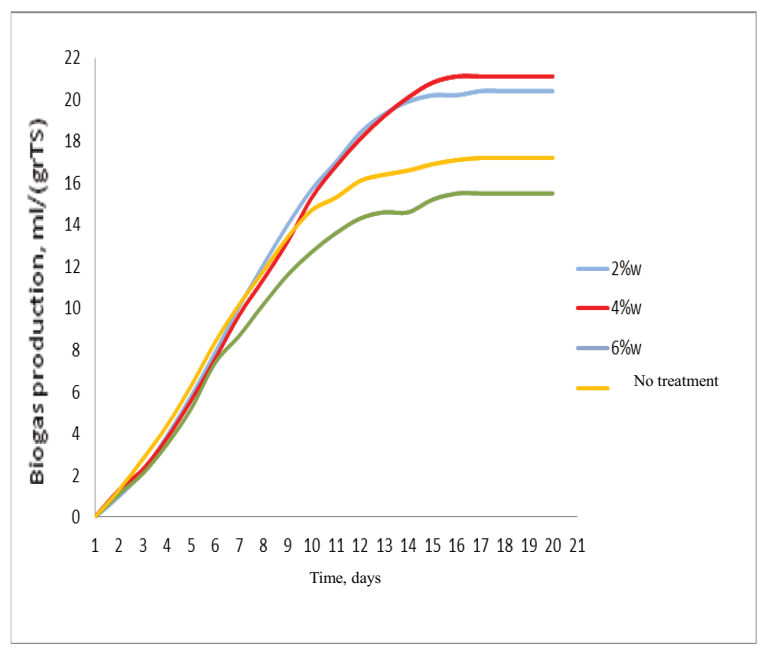

Fig. 3. Effect of Treatment $\mathrm{NaOH}$ to the production of biogas

In Figure 3 it can be seen that pretreatment using $\mathrm{NaOH} 4 \%$ w produced the highest volume of biogas of $21.1 \mathrm{ml} / \mathrm{rTS}$. At $\mathrm{NaOH} 2 \% \mathrm{w}$ only about $20.4 \mathrm{ml} / \mathrm{grTS}$ and the $\mathrm{NaOH} 6 \% \mathrm{w}$ has $16.6 \mathrm{ml} / \mathrm{grTS}$ while biogas without pretreatment has $17.2 \mathrm{ml} / \mathrm{grTS}$. Their initial treatment by using $\mathrm{NaOH}$ solution causes the volume of biogas produced is higher than the volume of biogas without pretreatment. Research conducted by Song et al. (2013) explained that with early treatment using $\mathrm{NaOH}$ 
alkaline solution will reduce lignin compounds in rice straw. The high concentrations of $\mathrm{NaOH}$ that used, then increasingly reduced lignin because $\mathrm{NaOH}$ will change microstructure of the cell walls of rice straw to facilitate microorganisms in fermentation process for production of biogas.

However, in a study with variable pretreatment $6 \%$ w $\mathrm{NaOH}$ showed the opposite result with the biogas production without pretreatment. The results obtained fewer in compare without pretreatment. This is because the addition of $\mathrm{NaOH}$ more than $4 \% \mathrm{w}$ during the process of pretreatment using $\mathrm{NaOH}$ can raise the concentration of the substrate and dissolving many carbohydrates (cellulose and hemicellulose) that are not effective in the process of pretreatment before the fermentation process [8]. At the time of cooking or soaking with $\mathrm{NaOH}$ causing excessive fiber (lignocellulose) becomes damaged and destroyed [23]. Therefore, the results obtained biogas is less than the biogas without pretreatment. [8] explains that methanogenic bacteria can operate optimally in the process of anaerobic digestion at $4 \% \mathrm{w} \mathrm{NaOH}$ is added to the substrate and if the addition of more than $4 \% \mathrm{w}$ $\mathrm{NaOH}$ then methanogenic bacteria do not effective for biogas production process.

\subsection{Effect of Acetic Acid Solution on Biogas Production from Rice Straw}

The addition of $\mathrm{CH}_{3} \mathrm{COOH}$ solution consists of three concentrations are at a concentration of $0.075 \mathrm{M}, 0.15 \mathrm{M}$ and at a concentration of $0.75 \mathrm{M}$. The difference in concentration on the addition of $\mathrm{CH}_{3} \mathrm{COOH}$ solution aims to determine the optimal conditions in the delignification using an alkaline solution to produce biogas. Here is the volume of biogas produced from a wide variety of variables pretreatment using a solution of acetic acid.

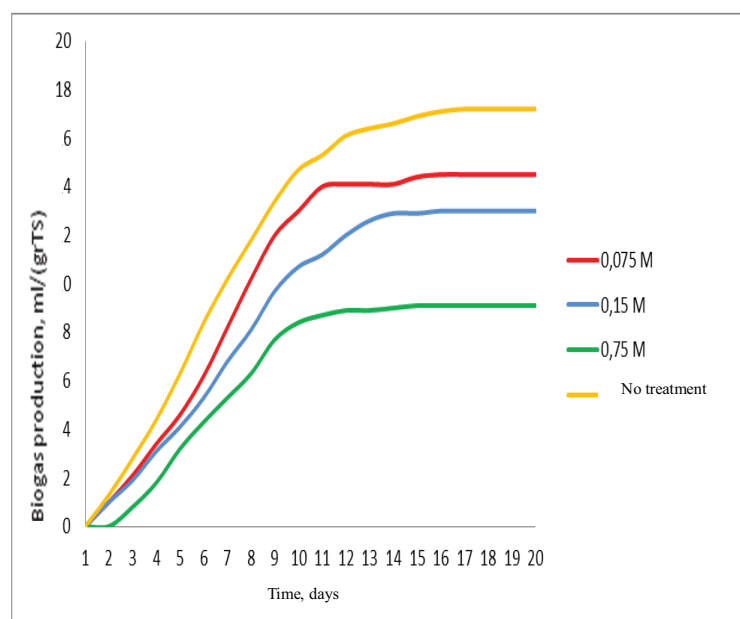

Fig. 4. Effect of early treatment of acetic acid to the production of biogas

In Figure 4 it can be seen that the volume of biogas produced in the absence of early treatment is higher compared to their initial treatment. In the control variables produce biogas volume was $17.2 \mathrm{ml} / \mathrm{grTS}$ while acetic acid treatment produces biogas lower volume is $14.5 \mathrm{ml} / \mathrm{grTS}$ at variable $0,075 \mathrm{M}, 13 \mathrm{ml} / \mathrm{grTS}$ at variable $0,15 \mathrm{M}$ and $9,1 \mathrm{ml} / \mathrm{grTS}$ the variable $0.75 \mathrm{M}$. In the study conducted by [16] explains that the lignin compound will not be degraded in strong acids. Another study conducted by [25] explains that the treatment using a weak acid such as acetic acid at low concentrations can also reduce the lignin content during the immersion process lasts a weak acid solution. Decreased levels of lignin in the amount of $7.15 \%$ to $16.88 \%$ lignin content. During the decreased levels of lignin, cellulose is separated from the structure of lignocellulose is converted methane microorganisms that will ease the process of rice straw decomposition by microorganisms for the production of biogas (Sari et al., 2014). This is due to the increase in the rate of hydrolysis due to greater volumes of hydrogen ions that will help the process of dissolving hemicellulose and lignin.

Another study conducted [17] explained that the process of acid delignification will cause the structure of lignin and hemicellulose which binds cellulose condensed and settled so that the cellulose will be free structure that is separate from the lignin and hemicellulose then will facilitate the access of enzymes or microorganisms to transform cellulose to become monomer - monomer sugars as nutrients for fermentation biogas. The decline lignin is also accompanied by a decrease in hemicellulose and cellulose which is the main nutrient that will use microorganisms to produce biogas, so the results obtained will be slightly [25]. Treatment using a weak acid solution is less effective in degrading lignin but it is more effective to reduce the levels of hemicellulose [17]. Therefore, research using a weak acid solution such as acetic acid is less effective that the results obtained biogas will also decrease because there are some cellulose is also dissolved at the time of immersion using a weak acid solution.

\subsection{Comparison of Treatment Early On Biogas Production From Rice Straw}

In these discussions are expected to compare the production of biogas between rice straw is given pretreatment acidified with pretreatment under alkaline conditions. The addition of acetic acid $\left(\mathrm{CH}_{3} \mathrm{COOH}\right)$ consists of three concentrations that are at a concentration of $0.075 \mathrm{M}, 0.15 \mathrm{M}$ and at a concentration of $0.75 \mathrm{M}$, while at the beginning of treatment using $\mathrm{NaOH}$ alkaline solution consists of three different variables are variables $2 \% \mathrm{w}, 4 \% \mathrm{w}$ and $6 \% \mathrm{w}$. Comparison of variables taken the most optimal results in each pretreatment. At the beginning of treatment in the form of the addition of acetic acid solution optimal concentration of $0.075 \mathrm{M}$, while the initial treatment using $\mathrm{NaOH}$ alkaline solution has a concentration of $4 \%$ optimal variable w. Differences in the two optimal concentration on each different pretreatment aims to determine the optimal conditions in the delignification chemical in producing biogas. Here is a comparison chart between the initial treatment using a solution of acetic acid and pretreatment using a solution of $\mathrm{NaOH}$. 


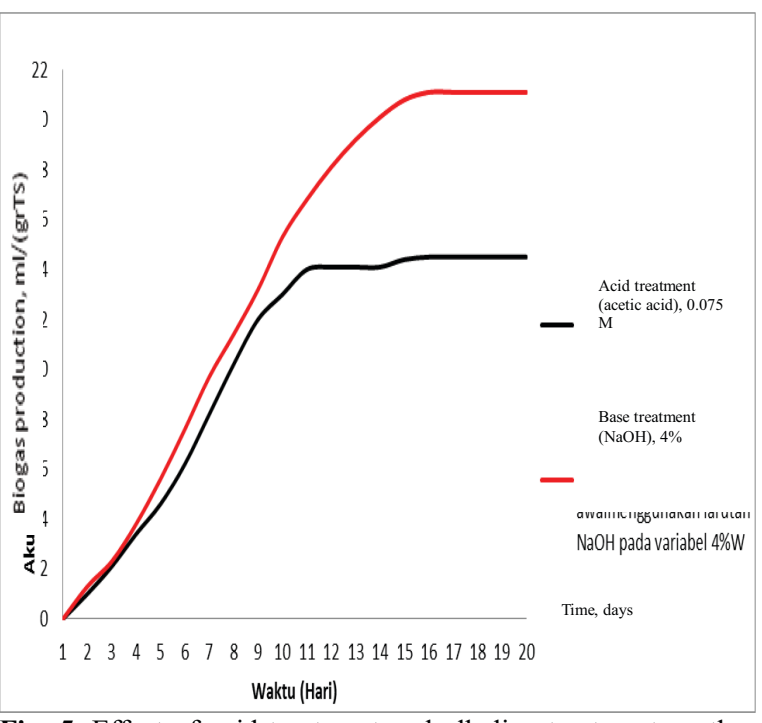

Fig. 5. Effect of acid treatment and alkaline treatment on the production of biogas

In the graph above it can be seen that pretreatment using $\mathrm{NaOH}$ alkaline solution is more effective in reducing the lignin compounds is compared pretreatment rice straw using acetic acid solution, so the treatment using a solution of $\mathrm{NaOH}$ produce biogas volume more than the treatment using acetic acid. Pretreatment with a solution of $\mathrm{NaOH}$ produce biogas volume of $21.1 \mathrm{ml} /$ grTS on variable $4 \% \mathrm{w}, 20.4 \mathrm{ml} / \mathrm{grTS}$ on variable $2 \% \mathrm{w}$ and $15.5 \mathrm{ml} / \mathrm{grTS}$ at $6 \% \mathrm{w}$ variable so that at the beginning of treatment using a base $\mathrm{NaOH}$ most optimum is at $4 \% \mathrm{w}$ variable with volume biogas obtained is $21.1 \mathrm{ml} / \mathrm{grTS}$. As for the initial treatment using a solution of acetic acid to produce biogas volume of $14.5 \mathrm{ml} / \mathrm{grTS}$ at 0.075 variable $\mathrm{M}, 13 \mathrm{ml} / \mathrm{grTS}$ on variables $0.15 \mathrm{M}$ and $9.1 \mathrm{ml} / 0.75 \mathrm{M}$ grTS variable so that the pretreatment conditions the optimum acid is at $0,075 \mathrm{M}$ variable with the volume of biogas produced $14.5 \mathrm{ml} / \mathrm{grTS}$. In the study conducted [17] explained that for decreased levels of lignin will simplify the process of rice straw decomposition by microorganisms. Cellulose is separated from the structure of lignocellulose is easier to convert into biogas microorganisms so that at the beginning of treatment using a solution of $\mathrm{NaOH}$ results obtained biogas is greater than the control variables or without pretreatment.

The process that occurs in the presence of the treatment using $\mathrm{NaOH}$ alkaline solution, namely the ester bond in the LCC (Lignin-carbohydrate complexes) were destroyed due to the reaction of hydrolysis to produce more cellulose for biogas production process. Inter bonding units and functional groups themselves lignin, cellulose and hemicellulose were also damaged. Changes in chemical composition and physical characteristics of rice straw causing it more easily degraded and increase the production of biogas [11]. At the beginning of treatment using acetic acid can also reduce lignin compounds. As the research conducted by [25] which explains that pretreatment in acidic conditions can lower the lignin content of $7.15 \%$ to $16.88 \%$, so that microorganism easier methane compounds convert cellulose to produce biogas. However, a decrease in lignin is also accompanied by a decrease in hemicellulose and cellulose which is the main nutrient that will use microorganisms to produce methane biogas so that the results obtained will be slightly [25].

Using $\mathrm{NaOH}$ solution is very effective and efficient in producing biogas as effective in reducing lignin compounds that exist in fiber or straw compared with the use of acetic acid as a solvent so that the cooking process is chemically good delignification used that delignification process using $\mathrm{NaOH}$ alkaline solution. Results biogas obtained is also greater than the treatment using acetic acid solution ie biogas volume of 6.6 $\mathrm{ml} /$ grTS more use of early treatment in alkaline conditions than treatment in an acidic state.

\subsection{Effect of Pretreatment to Lignocellulose Structure}

Pretreatment process in lignocellulosic materials needs to be done to ease the process of hydrolysis, namely to open up the structure of lignocellulose so that the cellulose more accessible to enzymes that break down polymeric polysaccharides into the form of monomers, so as to reduce the performance of a microorganism in biogas production and reduce costs during delignification [7].

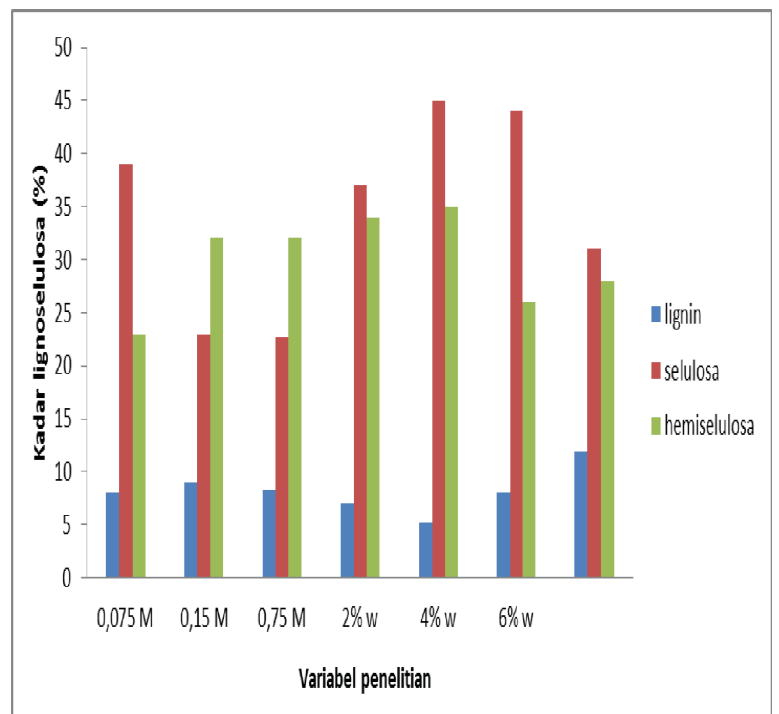

Fig. 6. Percentage change of lignin, hemicellulose and cellulose in the presence of pretreatment (acid and base) and without pretreatment

From the results of the analysis show that there have been a degradation of lignocellulosic components by six different variables after the initial treatment. Rice straw (Oryza sativa L.) were used in this study has a hemicellulose content of $28 \%, 31 \%$ cellulose content and lignin content of $12 \%$ which is the womb of control without the administration of pretreatment or pretreatment using either a solution of acetic acid or an alkaline solution of $\mathrm{NaOH}$. Lignin in the control variable is a component that has not experienced a significant reduction in all treatments. Decrease the highest lignin component in the treatment of straw with $\mathrm{NaOH} 4 \%$ to $5.2 \% \mathrm{w}$ lignin levels. Here is a table of analysis results in decreased levels of lignocellulose rice straw. 
Table 1. Lignocellulose content analysis in acid and alkaline delignification

\begin{tabular}{|c|c|c|c|c|}
\hline \multicolumn{2}{|c|}{ Variable } & $\begin{array}{c}\text { Lignin } \\
\text { content } \\
(\%)\end{array}$ & $\begin{array}{c}\text { Cellulose } \\
\text { content } \\
(\%)\end{array}$ & $\begin{array}{c}\text { Hemicelluloses } \\
\text { content }(\%)\end{array}$ \\
\hline \multirow{4}{*}{ Acid } & $0,075 \mathrm{M}$ & 8 & 39 & 23 \\
\cline { 2 - 5 } & $0,15 \mathrm{M}$ & 9 & 23 & 32 \\
\cline { 2 - 6 } & $0,75 \mathrm{M}$ & 8,3 & 22,7 & 32 \\
\hline \multirow{3}{*}{ Base } & $2 \% \mathrm{~W}$ & 7 & 37 & 34 \\
\cline { 2 - 6 } & $4 \% \mathrm{~W}$ & 5,2 & 45 & 35 \\
\cline { 2 - 6 } & $6 \% \mathrm{~W}$ & 8 & 44 & 26 \\
\hline \multicolumn{2}{|c|}{ Control } & 12 & 31 & 28 \\
\hline
\end{tabular}

The table 1 above shows that overall, decreased levels of lignin in the presence of either treatment using a solution of acetic acid or an alkaline solution of $\mathrm{NaOH}$. The cellulose content increased on average above $31 \%$ for the theoretical structure of lignocellulose rupture and separate cellulose from lignin and hemicellulose (Erviani et al., 2011). Characteristics of such cellulose do not dissolve in alkali, soluble in concentrated acid and insoluble in organic solvents and water (Ramdja et al., 2010). Therefore, in the variable using a solution of $\mathrm{NaOH}$ produces the most high cellulose content than using a solution of acetic acid as a solvent for delignification process. Cellulose is a polysaccharide component will be used microorganisms methane to be converted into simpler sugars monomer in the production of biogas. Cellulose that had high levels of naturally produced large volumes of biogas than cellulose with low levels.

In the table above shows also that the hemicellulose components decreased from $28 \%$ for the control variable to $23 \%$ to $26 \%$. Hemicellulose has the characteristics of soluble alkali ( $\mathrm{NaOH}$ solution is an alkaline solution) and soluble in acidic and susceptible to hydrolysis compared with cellulose [16]. Hence the hemicellulose content decreased.

\subsection{The influence Lignocellulose compounds on Biogas Production From Rice Straw}

In the study conducted by [13] described the structure of lignin is strong because lignin covalently bonded to the hemicellulose will result in cross link with the polysaccharide network which will add to the mechanical strength of the cell wall. The combination of lignin in the cell wall polysaccharides will prevent degradation by chemicals and pests. This causes difficulties methane microorganisms to convert polysaccharides into monomer sugar to be processed by microorganisms into biogas. Thus the initial treatment required so that the volume of biogas generated from optimal.

Components of rice straw (Oryza sativa L) has a hemicellulose content of $28 \%, 31 \%$ cellulose content and lignin content of $12 \%$. Cellulose component used to produce biogas. However, the difficulties encountered in lignocellulose degradation were a heterogeneous composition of the polysaccharides found in the cell wall that lignin compounds. In the plant tissue, is difficult to degrade lignin because it has a complex and heterogeneous structure that strengthens the plant structure in resisting against microbial attack and pressure oxidation [12].

Therefore the volume of biogas produced fewer and smaller than in the presence of delignification or pretreatment. At the hay with their initial treatment, the cellulose originally bonded to the structure of lignocellulose will decompose and despite making it easier for microorganisms to convert cellulose to manufacture biogas.

\section{Conclusions}

Pretreatment or delignification can affect the outcome of biogas obtained because of the presence of the pretreatment compound is lignin contained in plant tissues and arranged into lignocellulose will break its structure and degraded in the presence of $\mathrm{NaOH}$ solution which can reduce the lignin content of $12 \%$ (variable control) to $5.2 \%$ on a $4 \%$ w variable which is the optimum variables in the study so that the results obtained biogas is greater than the biogas on the control variable. At the beginning of treatment using a solution of acetic acid can lower the lignin content of $7.15 \%$ to $16.88 \%$ but reduced levels of lignin is accompanied by decrease in hemicellulose and cellulose of network structure in rice straw. Therefore, the treatment using acid solution is less effective when used for pretreatment or delignification process.

\section{References}

1. T. Anindyawati, Cellulase potential to degrade lignocellulosic agricultural waste to organic fertilizer (2010)

2. Budiyono, I.N. Widiasa, and S. Johari, Sunarso, World Academy of Science, Engineering and Technology, 37:983-988 (2010)

3. Budiyono, I. Syaichurrozi, S. Sumardiono, World Applied Sciences Journal 26(11): 1464-1472 (2013)

4. Budiyono, S. Iqbal, S. Siswo, Research Journal of Applied Sciences, Engineering and Technology 7(3):2798-2805 (2014)

5. Budiyono, I. Syaichurrozi and S. Sumardiono., International Journal of Engineering, Vol. 27(2):177-184 (2014)

6. Budiyono, S. Sumardiono and D. Tri Mardiani, International Journal of Engineering, 28(2): 921928 (2015)

7. Budiyono, I N. Widiasa, S. Johari, and Sunarso, International Journal of Engineering and Technology, 1(3):109-116 (2009)

8. Chandra, R., Takeuchi, H., Hasegawa, T., \& R. Kumar, Energy, 43(1):273-282 (2012)

9. I.W. Gunam, N.M. Wartini, Dewi Anggreni, A. M., \& P.M. Suparyana, Jurnal Teknologi Indonesia, 24$32(2011)$

10. Haghighi Mood, S., Hossein Golfeshan, A., Tabatabaei, M., Jouzani, G., Najafi, G., \& Gholami, Agroeconomy Research, 27:77-93 (2013)

11. Y. He, Y. Pang, Y. Liu, X. Li \& K. Wang, Energy \& Fuels, 22:2775-2781 (2008) 
12. A. Hendriks \& G. Zeeman, Bioresour Technology, 100(1): 10-18 (2009)

13. C.A. Hubbell \& A.J. Ragauskas, Bioresource Technology, 7410-7415 (2010)

14. S. Jin \& H. Chen, Industrial Crops and Products, 207-211 (2007)

15. Z. Lei, J. Chen, Z. Zhang \& N. Sugiura, Bioresource Technology, 4343-4348 (2010)

16. Ramdja, R. Silalahi \& N. Sihombing, Jurnal teknik Kimia Unsri. 17 (2010)

17. F. Sari \& Budiyono, Waste Technology, 2(1):17-25 (2014)

18. I. Sari, M. Izzati \& S. Haryanti, ejournal Undip, 45$55(2012)$
19. T. Silalertruksa \& S.A. Gheewala, Bioresource Technology, 150:412-419 (2013)

20. M. Stacey, Agric. Progress 51:69-78 (1976)

21. I. Syaichurrozi, B. Budiyono \& S. Sumardiono, Bioresource Technology, 149:390-397 (2013)

22. Sulardjo. Magistra . 81-90 (2013)

23. S. Wijana, A. Mulyadi \& A. Pratama, APTA Proceeding, 1-9 (2012)

24. A. Yulianingsih, F.D. Rahmawati, S. Amalia \& Wahyudin. Jurnal Biogas. (2012)

25. R. Zhao, Z. Zhang, R. Zhang, M. Li, Z. Lei \& M. Utsumi, Bioresource Technology, 101(3):990-994 (2010) 